\title{
Proportional Principles in Kumon Franchise Cooperation Agreement
}

\author{
Shafira Inan Zahida ${ }^{*}$, Ery Agus Priyono ${ }^{2}$, Dewi Hendrawati ${ }^{3}$ \\ \{Shafirainan@gmail.com ${ }^{* 1}$, eryap@live.undip.ac.id ${ }^{2}$, dewi.hendrawati@live.undip.ac.id ${ }^{3}$ \}
}

Fakultas Hukum, Universitas Diponegoro, Jl. Prof. H. Soedarto, S.H., Semarang, Indonesia $50275^{1}$

\begin{abstract}
Franchise is one form of standard agreement. The contents of the agreement are determined by the franchisor only, so that, in its contents, it allows an imbalance between the franchisor and the franchisee that will harm either party. This study addresses three issues, namely (1) Whether the agreement meets Article 1320 of the Civil Code, (2) Whether the agreement meets the principle of proportionality, (3) Legal consequences when the agreement does not meet the principle of proportionality. The research approach method used in writing this law is Normative Juridical. Normative jurisdiction is done by examining library materials which are secondary data. The results of the Kumon franchise agreement meet all the legal conditions of the agreement. The contents of the franchise agreement are found several articles that do not meet the principle of proportionality, although the Kumon franchise agreement can still be said to be valid and binding on the parties that made it because this agreement has met Article 1320 of the Civil Code.
\end{abstract}

Keywords: franchise, proportionality principle, standard agreement

\section{Introduction}

\subsection{Background}

Most countries in the world in the current global era try to develop their economies and expand economic activities to various countries, especially to developing countries by expanding their businesses, so that these countries can continue to be recognized in economic activities and international trade.[1] One way of expansion carried out by large countries is by doing franchise business in various countries, including in Indonesia.

Franchising began in the United States in the 1950s marked by the emergence of "giant" franchises in the field of fast food, Kentucky Fried Chicken founded by Colonel Harlan Sander's (1950) and McDonald`s by Maurice and Dick McDonald's (1955) ). McDonald`s then thrived on Ray Kroc's services.[2]

The development of the franchise business in Indonesia until March 1996 is estimated to have operated 119 foreign franchises, while the local franchise is estimated to be around 32 companies. Franchises nearly doubled with an estimation at around 70 companies in 2004.[3]

This Franchise Agreement is the granting of permission from the Franchisor to use Intellectual Property Rights (hereinafter referred to as IPR) to the Franchise Recipient by paying royalties for the use of the IPR. It also can be said that franchise is a granting for a 
license covering various Franchisor's Intellectual Property Rights, for example, trade names, logos, design or patent. So that the parties can provide mutual benefits to each other.[4]

The agreement in book III of the Civil Code adheres to an open system, which means that the parties are free to enter into an agreement with anyone, determine the conditions, the implementation and the form of the contract, both oral and written, in addition, are allowed to make good agreements that have been known in the Civil Code and outside the Civil Code. [5] Franchise agreement is a contract outside the Civil Code. The franchise agreement is regulated in Government Regulation No. 42 of 2007 concerning Franchising is the main foundation about franchising.[6]

According to Article 1313 of the Civil Code, an agreement is an act by which one or more persons are bound to one or more persons. An agreement can be said to be valid if it has fulfilled the provisions contained in Article 1320 of the Civil Code explaining that in an agreement to be valid it is required to fulfill the following conditions:

1. Agree those who bind themselves;

2. The ability to make an engagement;

3. A certain thing

4. A lawful cause.

Franchise agreements basically use the standard agreement system. A standard agreement is an agreement whose contents are made by one party, and the other party cannot express his will freely so that there is no bargaining about the contents of the agreement.[7] In order to keep the franchise agreement working to guarantee and protect the interests, rights, and obligations of the parties, the franchise agreement must fulfill several principle. One of the principles that work best to deal with this case is the principle of proportionality.

\subsection{Formulation of the problem}

Based on the above background, the authors raise the problem as follows:

1. Is the contents of the Kumon franchise agreement in accordance with the legal conditions of the agreement according to Article 1320 of the Civil Code?

2. How is the application of the proportionality principle in the Kumon franchise agreement?

3. What are the legal consequences if an agreement does not fulfill the principle of proportionality?

\section{Method}

The method of approach used in this study is the normative juridical approach. This research uses descriptive - analytical specifications. Data analysis method used in this research is qualitative analysis.

\section{Results and Discussion}

\subsection{Kumon History}


Kumon is one of the institutions in Indonesia. Law Number 20 of 2003 Article 26 paragraph (5) explains that the Course and Training is a form of continuing education to develop students' abilities with an emphasis on mastering skills andcompetency standards, and developing entrepreneurial attitudes and professional personality development. The basic principle of the Kumon method which was disseminated to Indonesia in October 1993 is the recognition of the individual potential and abilities of each student, to develop this potential to the fullest, guidance and a supportive environment are needed without limiting the age of the student.[8]

Kumon was born from a father's love for his son in 1945. Toru Kumon is a talented high school mathematics teacher, and when he saw his son, Takeshi, not excelling in mathematics in his school. He writes math worksheet problems to be solved by his son every day. Toru Kumon believes that educators have a responsibility to foster a mindset of independent learning in children, so he created teaching materials for Takeshi that can encourage him to learn independently.[9]

Toru Kumon, founded The Osaka Institute of Mathematics in 1958 in the city of Osaka, from then on, Kumon gave learning opportunities to as many children as possible.[10] Kumon first opened an overseas class in New York, United States in 1974. In this case, a Japanese family whose children had studied with Kumon in Japan moved to America along with the transfer of their father's work there. They requested that Kumon be available for children who moved abroad to meet the needs of students and their parents who moved abroad so the Kumon class opened the first Mathematics Class in New York, United States.[10]

Kumon established the group management structure in 2000. Each regional head office at that time stepped up its efforts to advance and support the Kumon Method and help to find a place in the local community. The 2008 marked the 50th anniversary of the founding of Kumon.[10] For more than 50 years, more than 16 million students around the world have experienced the results of the Kumon Method Learning. [11]

\subsection{Application of Legitimate Agreement Terms (Article 1320 Civil Code) in the Kumon Franchise Agreement}

The agreement is considered valid if it has fulfilled the conditions specified in Article 1320, namely:

1. Agree those who bind themselves;

2. The ability to make an engagement;

3. A certain thing;

4. A lawful cause;

\subsubsection{Agree those who bind themselves}

Based on this Kumon Franchise Agreement, the parties namely the Kumon Institute of Education Company Limited as the franchisor and the Human Resources Development Foundation, Lestari as the franchisee have agreed to make a Franchise Agreement and agree to the matters stipulated in the contents of the agreement. This can be seen in the premise contained in the agreement:

"Therefore, taking into account the agreements and agreements herein, the parties hereby agree to enter into a Franchise Agreement with the following terms and conditions." 
The parties agreement also has a signature on the closing of this Franchise agreement. Signing was carried out by Sary Halim as the Franchisee representing the Human Resources, Sustainable and Takeshi Kumon Development Foundation as the Franchisor representing the Kumon Institute of Education Company Limited.

\subsubsection{The ability to make an engagement}

The franchisor, in this agreement, is the Kumon Institute of Education Company Limited. Comapany Limited (Co.Ltd) or Limited Liability Company is described in Article 1 of Law Number 40 of 2007 concerning Limited Liability Companies which explains the Company is a legal entity based on this understanding.[12]

The franchisees in this agreement are the Human Resources Development Foundation, Sustainable. Foundations are explained in Article 1 number 1 of Law Number 16 of 2001 concerning Foundations which explains that foundations are legal entities.[13]

Legal entities as legal subjects in addition to humans who are considered to be able to act in law and who have rights, obligations and legal relations with other people and other bodies, so based on the description above the company and foundation are legal entities that have rights and obligations so The Kumon Institute of Education Company Limited and the Human Resources Development Foundation, Lestari are legal subjects who can enter into agreements.[14]

\subsubsection{A Certain Thing}

A certain thing in this agreement is that the franchisor will give the franchisee the right to use the expertise, experience and thoughts of the Franchisor and the use of the Franchisor Brand, information from suppliers related to the Kumon System, and conduct a Kumon System Course in Place for a certain period of time.

\subsubsection{A Halal cause}

Article 1320 of the Civil Code does not explain the definition of halal causa. In Article 1337 the Civil Code only states that prohibited causa. A cause is forbidden if it conflicts with the law, decency and public order.

The object of the agreement in this franchise agreement is the License. The license which is the object of this study is a lawful thing because it does not violate the provisions of the law, decency, and public order if done in accordance with the laws and regulations of Law Number 26 of 2014 concerning Copyright which regulates the license.[15] So that this agreement has fulfilled the fourth condition of the validity of the agreement which is a halal cause.

Based on the above analysis, it can be concluded that this Franchise Kumon agreement has fulfilled the four legal requirements for the formation of an agreement based on the provisions stipulated in Article 1320 of the Civil Code, so that this agreement can be said to be valid and binding on both parties bound therein.

\subsection{Application of the Principle of Proportionality in the Kumon Franchise Agreement}

Under the Kumon franchise agreement, according to the author, there are several Articles that do not meet the application of the principle of proportionality, namely:

\subsubsection{Article 7.1 concerning insurance}

This article explains that Frachisee must bear the burden of compensation to the Franchisor himself and release the Franchisor from any student, member or third party 
demands arising from the implementation of the Kumon Course System. According to the author, the contents of this article are deemed not to meet the principle of proportionality because the Franchisee must take responsibility for the demands of students, Members, or third parties as well as the franchisee must also provide compensation for Franchisor's compensation due to the holding of the Kumon System Course. The Franchisor should be responsible for organizing the Kumon System Course because in organizing matters in the Kumon System Course the Franchisee must first approve the Franchisor, the franchisor should take responsibility if there is a loss or demand from students, Members or third parties.

\subsubsection{Article 9.3 concerning the prohibition on terminating the agreement}

This article explains that in terminating the agreement due to any reason the franchisee is not allowed either alone or together directly or indirectly to do or join or think or wish in the education system that will compete with the Kumon System in Indonesian territory for a period of five years. The formulation in this article, according to the author, does not fulfill the principle of proportionality because the existence of this article is deemed to be detrimental to the franchisee. Franchisees after the termination of this agreement cannot develop their business opportunities independently because there are restrictions as stated in this article.

\subsubsection{Article 10.6 concerning termination of the agreement}

Article 10.6 explains that all Franchisees' rights and interests in this agreement will automatically terminate if the franchisee is bankrupt, unable, or liquidated or in another case, the appointment of a recipient or guardian for the Franchisee or cessie or a temporary suspension of the operation of the Kumon System Course. Article 10.6 contains:

"This agreement and all rights contained therein (except Article 9 will continue to apply in the interest of the Franchisor) will automatically terminate jointly with all the rights and interests of the Franchisee here, without any notification to the Franchisee in the event that the Franchisee is bankrupt, unable or being liquidated or the appointment of a recipient or guardian for Franchisees or casie or temporary suspension of the Kumon System Course."

This article is deemed not fulfilling the principle of proportionality because of the termination or termination of franchisee rights and obligations, it is better for the franchisor to make advance notice and grace period for the franchisee regarding termination or termination of rights and obligations. According to the authors, it was felt that the relationship between the rights and obligations between the two remained clear until the conclusion of the agreement made by the parties.

\subsubsection{Article 10.9 concerning termination of the agreement}

Article 10.9 explains that the parties will waive the entry into force of Article 1266 of the Civil Code, so that if an agreement can be canceled, the judge must not request it, in other words the parties in the agreement can cancel this agreement themselves.

Which according to Agus Yudha Hernoko by emphasizing the formulation of termination "must be requested to the Court", the word "must" in the provisions of Article 1266 of the Civil Code is interpreted as a rule that is compelling (dwingend recht) and therefore should not be ruled out by the parties through their agreement clauses. the author in making the agreement should not rule out Article 1266 of the Civil Code because according to the grammatical itself in Article 1266 the Civil Code there is the word "must" which indicates the 
existence of obligations and these are compulatory provisions so that according to the author this Article cannot be ruled out. [16] This article does not show the principle of proportionality because the Franchisor will find it easier to terminate this agreement unilaterally because it is not necessary to ask the judge in advance with a protracted process.

\subsection{Legal consequences if the agreement does not fulfill the principle of proportionality}

Lindawaty Sewu stated that if the terms of the legality of the agreement as stipulated in Article 1320 of the Civil Code have been fulfilled, then based on article 1338 of the Civil Code, the agreement will have the same legal force as the law as long as it does not conflict with the law, decency and public order, must also fulfill the conditions for validity of the agreement.[3]

This agreement fulfills the legal requirements of Article 1320 of the Civil Code and is carried out in good faith and does not conflict with legislation, decency and public order, so that this agreement fulfills the provisions of Article 1338 of the Civil Code, and as long as the parties, both the Franchisor and Franchisee, perform achievements - the achievement as stated in this agreement and does not breach the contract, then this agreement does not fulfill the conditions for canceling an agreement as referred to in Article 1265 of the Civil Code.

The franchise agreement between the Kumon Institute of Education Company Limited and the Human Resources Development Foundation has several articles, in which, according to the author, do not apply the principle of proportionality, namely Article 7, Article 9.3, Article 10.6, Article 10.9, and Article 15.5. An agreement that does not meet the principle of proportionality in it there is no proportion of the distribution of rights and obligations between parties that takes place properly and properly, and with the principle of proportionality not fulfilled, there is no exchange of rights and obligations of the parties that are fair.

The principle of proportionality is not one of the four legal conditions of an agreement. So, if an agreement does not fulfill the principle of proportionality as long as the agreement meets the legal requirements of an agreement provided for in Article 1320 of the Civil Code and the contents of the agreement do not violate the law, decency and public order, then this agreement will remain a valid.. So, based on the description above the franchise agreement between the Kumon Institute of Education Company Limited and the Human Resources Development Foundation, Lestari is a legal agreement and is binding on the parties.

\section{Conclusion}

Based on the description, the conclusions can be drawn as follows:

1. The franchise agreement between the Kumon Institute of Education Company Limited and the Human Resources Development Foundationhas fulfilled all the legal requirements of the agreement as stipulated in Article 1320 of the Civil Code. The requirements for Article 1320 of the Civil Code are fulfilled:

a. The agreement of both parties to this agreement is marked by the premise that both parties agree to enter into an agreement, and signatures from both parties are available.

b. The prowess to make an agreement in this agreement is carried out between PT and the Foundation as a party. Based on Article 1 number 1 of Law Number 16 of 2001 concerning Foundations, foundations are legal entities, and based on Article 1 of 
Law Number 40 of 2007 concerning Limited Liability Companies, PT is a legal entity. A legal entity is the subject of an agreement because it has rights and obligations so it can be said to be competent to make an agreement.

c. A Certain Thing. In this agreement the object of the agreement is that the Franchisor gives the franchisee a license, and the license is a predetermined object.

d. A Halal cause. The object of the agreement is a license where the license is a lawful thing because it does not violate the provisions of the law. The license is regulated in Law Number 28 Of 2014 concerning Copyright. License also does not violate decency and public order so that the License is a lawful cause.

2. Franchise Agreement between Kumon Institute of Education Company Limited and Sustainable Human Resources Development Foundation is not in accordance with the Proposionality Principle. An agreement that meets the Proposionality principle will provide recognition of the rights, opportunities, and opportunities for the parties to determine the contents of an agreement. This agreement considers as standard agreement so that the contents of this agreement are only made by the Franchisor; therefore, the franchisee is only given the option to take or leave the contract. This agreement also contains several articles that are considered unfair and detrimental to the franchisee, namely Article 7.1 concerning insurance, Article 9.3 concerning the termination of the agreement, Article 10.6 and Article 10.9 concerning termination of the agreement, and Article 15.5 concerning the right to transfer.

3. The Franchise Agreement between the Kumon Institute of Education Company Limited and the Sustainable Human Resources Development Foundation is indeed not fulfilled in this agreement. According to Article 1320, the legal condition of an agreement is the agreement of those who bind themselves, the ability to make an engagement, a certain matter, and a lawful cause. This agreement has fulfilled all four legal conditions of the agreement. Article 1338 of the Civil Code allows making agreements in the form of any content as long as the agreement is implemented in good faith. Thus, it can be said that the agreement can contain anything as long as it still meets the legal requirements of the agreement in Article 1320 of the Civil Code, and the agreement is carried out in good faith. So that even though this agreement does not fulfill the Principle of Proportionality, this agreement is still considered valid and binding. 


\section{References}

[1] C. Malik, "Implikasi Hukum Adanya Globalisasi Bisnis Franchise," J. Huk. Ius Quia Iustum, vol. 14, no. 1, pp. 97-113, 2007.

[2] Ilhamdi, "Perjanjian Kerjasama Waralaba Antara PT. Raos Aneka Pangan Dengan NY. HJ. Maryenik Yanda,” JOM Fak. Huk., vol. 1, no. 2, pp. 1-15, 2014.

[3] P. L. Sewu, Franchise: pola bisnis spektakuler (dalam perspektif hukum \& ekonomi). Bandung: Utomo, 2004.

[4] P. R. Listyawati, "Perjanjian Franchise sebagai Perjanjian Innomenaat dalam Pandangan Hukum Perdata,” J. Huk. Fak. Huk. Univ. Islam Sultan Agung, vol. 17, no. 2, 2006.

[5] R. Gumanti, "Syarat Sahnya Perjanjian (Ditinjau dari KUHPerdata)," J. Pelangi Ilmu, vol. 50, no. 1, pp. 1-13, 2012.

[6] Government Regulation No. 42 of 2007 concerning Franchising. .

[7] C. Pangalila, "Kajian Hukum Terhadap Sanksi Dan Larangan Klausula Baku Menurut UU No. 8 Tahun 1999 Tentang Perlindungan Konsumen," Lex Priv., vol. 3, no. 3, 2015 .

[8] N. Widiawati and D. Sofyan, "Perbandingan Prestasi Belajar Matematika Siswa antara yang Mendapatkan Metode Kumon dan Metode Konvensional," Mosharafa, vol. 2, no. 2, pp. 99-110, 2013.

[9] Kumon, "Our History." [Online]. Available: https://www.kumon.org/our-history/. [Accessed: 12-Feb-2020].

[10] Kumon Global, "Our Milestones Achievements." [Online]. Available: https://id.kumonglobal.com/discover/our-milestones-achievements/. [Accessed: 12Feb-2020].

[11] Kumon "History." [Online]. Available: https://www.kumonsunnyvale.com/history. [Accessed: 12-Feb-2020].

[12] Law Number 40 of 2007 concerning Limited Liability Companies. .

[13] Law Number 16 of 2001 concerning Foundations. .

[14] D. H. Prananingrum, "Telaah Terhadap Esensi Subjek Hukum: Manusia Dan Badan Hukum,” Refleks. Huk. J. Ilmu Huk., vol. 9, no. 2, pp. 73-92, 2014.

[15] Law Number 26 of 2014 concerning Copyright. .

[16] A. Y. Hernoko, Hukum perjanjian asas proporsionalitas dalam kontrak komersial. Jakarta: Kencana, 2010. 